\title{
PENGARUH PEMBERIAN OVAPRIM DAN HUMAN CHORIONIC GONADOTROPIN (hCG) TERHADAP PEMIJAHAN SIPUT GONGGONG Laevistrombus turturella
}

\section{EFFECT OF OVAPRIM AND HUMAN CHORIONIC GONADOTROPIN (hCG) ADMINISTRATION ON GONGGONG CONCH Laevistrombus turturella SPAWNING}

\author{
Muzahar $^{1 *}$, Wiwin Kusuma Atmaja Putra ${ }^{1}$, Aminatul Zahra ${ }^{1}$, \& Lily Viruly ${ }^{2}$ \\ ${ }^{1}$ Program Studi Budidaya Perairan, FIKP-UMRAH, Tanjungpinang, 29115, Indonesia \\ ${ }^{2}$ Program Studi Teknologi Hasil Perikanan, FIKP-UMRAH, Tanjungpinang, 29115, Indonesia \\ "E-mail: mzet.oke@gmail.com
}

\begin{abstract}
The success of spawning determines the availability of gonggong conch seeds. The purpose of this study was to analyze the effectiveness of different types of hormones namely ovaprim ${ }^{\circledR}$ and $h C G$ in stimulating the spawning of gonggong conch. Eighty-four pairs of broodstock were injected according to the design with ovaprim ${ }^{\circledR}$ or $h C G$, or combination of both hormones at a dose of $0.5 \mu \mathrm{L} / \mathrm{g} B W$. Post-injection broodstock are spawned in an aquarium with a density of 7 pairs per aquarium. The observed parameters were the number of spawned broodstocks, the number of released eggs, the latency time, and the histological of the broodstock gonads. The Kruskal Wallis test was used to analyze the number of spawned broodstock, and the analysis of variace (ANOVA) was used to analyze the number of released eggs. The results showed that there was no significant differences between the treatments $(P>0.05)$ on the number of spawned broodstocks, but hCG administration gave the highest number of spawned broodstocks (52.38\%). The latency time of broodstock spawned generally began on the 2 nd and $3 r d$ day after $0.5 \mu L / g ~ B W$ ovaprim administration. Based on the percentage of spawned broodstock and the value of all observation parameters, it was concluded that the $h C G$ with a dose of 0.5 $\mu L / g B W(P 1)$ gives a better response than the other treatments.
\end{abstract}

Keywords: gonggong conch, hCG, Laevistrombus turturella, ovaprim ${ }^{\circledR}$, spawning

\begin{abstract}
ABSTRAK
Keberhasilan pemijahan menentukan ketersediaan benih siput gonggong. Tujuan penelitian ini adalah menganalisis efektivitas penggunaan jenis hormon berbeda yaitu ovaprim ${ }^{\circledR}$ dan hCG dalam menstimulasi pemijahan siput gonggong. Delapanpuluh empat pasang induk disuntik sesuai rancangan dengan ovaprim ${ }^{\circledR}$ atau $\mathrm{hCG}$, atau kombinasi keduanya masing-masing dengan dosis $0,5 \mu \mathrm{L} / \mathrm{g} \mathrm{BB}$. Induk pascasuntik dipijahkan dalam akuarium dengan densitas 7 pasang per akuarium. Parameter yang diamati adalah: jumlah induk yang memijah, jumlah telur dikeluarkan oleh induk, waktu latensi, dan tampilan histologi gonad induk. Uji Kruskal Wallis digunakan untuk menganalisis data jumlah induk mijah, dan analysis of variance (ANOVA) untuk menganalisis jumlah telur dikeluarkan oleh induk siput. Hasil penelitian menunjukkan tidak ada perbedaan signifikan $(\mathrm{P}>0,05)$ jumlah induk mijah di antara perlakuan, namun pemberian hCG memberikan jumlah induk mijah paling tinggi $(52,38 \%)$. Waktu latensi induk mijah umumnya mulai mijah pada hari ke-2 dan ke-3 setelah pemberian 0,5 $\mu \mathrm{L} / \mathrm{gBB}$ ovaprim. Berdasarkan persentase induk mijah dan nilai seluruh parameter pengamatan disimpulkan bahwa pemberian suntikan hCG dosis $0,5 \mu \mathrm{L} / \mathrm{g}$ BB (P1) memberikan respons lebih baik dibanding perlakuan lain.
\end{abstract}

Kata kunci: hCG, Laevistrombus turturella, ovaprim®, pemijahan, siput gonggong. 


\section{PENDAHULUAN}

Siput gonggong (L. turturella) merupakan siput laut dari Famili Strombidae yang paling banyak dieksploitasi dan dikonsumsi oleh masyarakat kota Tanjungpinang karena citarasanya yang lezat dan mengandung protein tinggi 46,65\% (Muzahar \& Viruly, 2014). Cangkang siput gonggong dimanfaatkan sebagai bahan kerajinan tangan (souvenir) seperti bunga, bros dan gantungan kunci yang harganya cukup terjangkau. Siput ini memiliki lima varian morfologi, namun yang paling banyak disajikan sebagai lauk pauk adalah yang bercangkang tebal (Muzahar et al., 2018; Muzahar \& Viruly, 2014). Siput gonggong kebanyakan hidup di habitat lumpur berpasir atau pasir berlumpur dan sedikit yang hidup di habitat pasir. Sentra penangkapan siput gonggong antara lain adalah di perairan laut Pulau Bintan (di daerah Madong, Tanjung Sebauk, Senggarang, Kelam Pagi, Batu Licin, Desa Busung, Lobam dan Tembeling), Pulau Dompak, Penyengat dan Pengujan. Kemungkinan populasi siput ini di alam telah mengalami tangkap lebih untuk memenuhi permintaan pasar sehingga terjadi penurunan. Ukuran dan jumlah siput gonggong hasil tangkapan yang diperoleh para nelayan semakin kecil (Muzahar \& Hakim, 2018). Overexploitation pada keong Strombus canarium telah terjadi di Selat Johor, Malaysia (Cob et al., 2008). Kegiatan budi daya dapat meningkatkan produksi gonggong dan melestarikan populasinya di alam. Produksi budi daya dapat memperbaiki populasi siput gonggong melalui restocking dan dapat mengurangi penangkapan di alam. Titik awal dan kunci sukses dalam usaha budi daya perikanan adalah pembenihan (Afriani, 2016). Pembenihan adalah salah satu kegiatan utama dalam budi daya siput gonggong. Keberhasilan pembenihan sangat dipengaruhi oleh keberhasilan pemijahan induk siput gonggong.

Kendala utama pembenihan siput gonggong adalah masih rendahnya tingkat pemijahan induk dan tingkat kelangsungan hidup (survival rate, SR) larva di wadah budi daya (Muzahar et al., 2019), disamping itu sumber induk matang gonad masih mengandalkan penangkapan dari alam. Salah satu cara yang paling efektif dalam menstimulasi pemijahan organisme akuatik adalah melalui manipulasi hormonal (Yudha et al., 2017). Proses reproduksi siput laut Thais clavigera dan kerang Sinonovacula constricta dikendalikan oleh hormon (Lu et al., 2001; Yan et al., 2011). Pemijahan kerang Placopecten magellanicus berhasil diinduksi dengan pemberian hormon testosteron dan 17 $\beta$-estradiol (Wang \& Croll, 2006).

Ovaprim ${ }^{\circledR}, \quad$ human chorionic gonadotropin (hCG), atau kombinasi keduanya luas digunakan dalam memicu pemijahan ikan. Penggunaan hCG dengan dosis $250 \mathrm{IU} / \mathrm{kg}$ bobot tubuh (BB) mampu menstimulasi pemijahan ikan bawal bintang (Trachinotus blochii) (Mulah et al., 2017; Putra et al., 2018), ikan tengadak (Barbonymus schwanenfeldii) (Dewantoro et al., 2017), serta ikan lele dumbo (Clarias gariepinus) (Sinjal, 2014). Penggunaan kombinasi ovaprim ${ }^{\circledR}$ dosis $0,7 \mathrm{~mL} / \mathrm{kg}$ dan hCG dosis $500 \mathrm{IU} / \mathrm{kg}$ memberikan respons pemijahan terbaik pada ikan agamysis (Agamyxis albomaculatus) (Nur et al., 2017). Pemberian ovaprim ${ }^{\circledR}$ pada siput ini tercatat baru satu penelitian, yaitu dengan dosis rendah $0,5 \mu \mathrm{L} / \mathrm{g}$ bobot tubuh lunak (BB) menghasilkan induk betina yang memijah lebih banyak daripada dosis $0,7 \mu \mathrm{L} / \mathrm{g}$ BB dan $0,9 \mu \mathrm{L} / \mathrm{g} \mathrm{BB}$, berturut-turut sebesar 34,48\%, 27,59\% dan 20,69\% (Muzahar et al., 2019). Penelitian tentang pemberian hCG, dan kombinasi dengan ovaprim ${ }^{\circledR}$ untuk memicu pemijahan siput gonggong tidak pernah dilaporkan sehingga sehingga perlu dikaji.

Tujuan penelitian ini adalah untuk menganalisis (1) jenis hormon yang lebih efektif dalam menginduksi pemijahan siput gonggong ditinjau dari jumlah induk mijah dan waktu latensinya, (2) jumlah telur yang 
dikeluarkan oleh siput gonggong, dan (3) perbedaan profil histologis gonad induk yang mijah dan tidak mijah.

\section{METODE PENELITIAN}

\subsection{Waktu dan Lokasi Penelitian}

Penelitian ini telah dilaksanakan pada bulan Maret-Juli 2020 di Marine Aquaculture Laboratory dan Marine Biology Laboratory, Universitas Maritim Raja Ali Haji, Tanjungpinang. Induk siput gonggong yang digunakan berasal dari tangkapan dari empat titik sampel di laut Madong-Kota Tanjungpinang seperti disajikan pada Table 1. Tipe substrat di lokasi ini umumnya adalah lumpur berpasir dengan vegetasi lamun dengan kepadatan sedang (Muzahar et al., 2019). Preparat histologi gonad induk siput dikerjakan oleh Laboratorium Kesehatan Ikan, Departemen Budidaya Perairan FPIK-IPB University.

\subsection{Rancangan Percobaan}

Rancangan penelitian yang digunakan adalah rancangan acak lengkap (RAL) dengan empat perlakuan dan tiga ulangan. Jumlah siput uji yang dipakai berjumlah 168 ekor (84 pasang). Dosis dan volume larutan hormon per gram bobot badan lunak (BB) yang disuntikkan pada siput gonggong berpedoman pada Muzahar et al. (2019) yaitu $0,5 \mu \mathrm{L} / \mathrm{g}$ BB. Bobot badan lunak rata-rata siput gonggong adalah $10,7 \pm 3,4$ g/ekor (betina) dan $8,1 \pm 2,3$ g/ekor (jantan). Volume hormon disuntikkan pada induk adalah hasil perkalian dosis yang diberikan dengan bobot badan lunak rata-rata siput gonggong seperti ditampilkan pada Table 2. Wadah yang dipakai adalah dua belas buah akuarium masing-masing berukuran $(80 \times 40 \times 50) \mathrm{cm}^{3}$.

Table 1. The coordinates of the gonggong conch sampling area.

\begin{tabular}{|c|c|c|}
\hline No. & The coordinate & Information \\
\hline 1 & $104^{\circ} 26^{\prime} 2.714^{\prime \prime B T}$ & Location 1 \\
\hline & $0^{\circ} 58^{\prime} 58.563 " \mathrm{LS}$ & \\
\hline 2 & $\begin{array}{l}104^{\circ} 26^{\prime} 8.025^{\prime \prime B T} \\
0^{\circ} 58^{\prime} 55.907^{\prime L S}\end{array}$ & 22 \\
\hline 3 & $\begin{array}{l}104^{\circ} 26^{\prime} 12.565^{\prime B T} \\
0^{\circ} 58^{\prime} 56.507 " \mathrm{LS}\end{array}$ & n 3 \\
\hline 4 & $\begin{array}{l}104^{\circ} 26^{\prime} 16.42^{\prime \prime B T} \\
0^{\circ} 58^{\prime} 59.762^{\prime \prime} \mathrm{LS}\end{array}$ & on 4 \\
\hline
\end{tabular}

\subsection{Penyiapan Wadah Pemeliharaan}

Seluruh akuarium untuk wadah pemeliharaan induk pascasuntikan dibersihkan dan dipasang seperangkat aerator. Sedimen lumpur sebagai pakan untuk induk diambil dari habitat alami siput gonggong diletakkan di dasar semua akuarium sampai ketinggian $10 \mathrm{~cm}$. Air dimasukkan ke dalam semua akuarium sampai ketinggian $45 \mathrm{~cm}$, dan kemudian aerator diaktifkan (Muzahar \& Hakim, 2018).

\subsection{Penyiapan Siput Uji, Ovaprim ${ }^{\circledR}$ dan hCG, dan Teknik Pemijahan}

Siput gonggong uji memiliki panjang cangkang >67 mm (betina) dan $>64 \mathrm{~mm}$ (jantan) dan bobot badan lunak tanpa cang-

Table 2. Treatments, injection volume of $h C G$ hormone and ovaprim®.

\begin{tabular}{|c|c|c|}
\hline Treatments & $\begin{array}{c}\text { Volume of injection } \\
\text { ( } \mu \text { L/ekor) on female } \\
\text { broodstock }\end{array}$ & $\begin{array}{c}\text { Volume of injection } \\
\text { ( } \mu \text { L/ekor) on male } \\
\text { broodstock }\end{array}$ \\
\hline Dosage of $0.5 \mathrm{IU} / \mathrm{g} \mathrm{BB}$ hCG (P1) & 5.35 & 4.05 \\
\hline Dosage of $0.5 \mu \mathrm{L} / \mathrm{g}$ BB ovarim ${ }^{\circledR}(\mathrm{P} 2)$ & 5.35 & 4.05 \\
\hline $\begin{array}{l}\text { Dosage of } 0.25 \mathrm{IU} / \mathrm{g} \text { BB hCG }+0.25 \mu \mathrm{L} / \mathrm{g} \\
\text { BB ovaprim }{ }^{\circledR}(\mathrm{P} 3)\end{array}$ & 5.35 & 4.05 \\
\hline $\begin{array}{l}\text { Dosage of } 0.5 \mu \mathrm{L} / \mathrm{g} \quad \mathrm{BB} \text { physiological } \\
\text { solution } \mathrm{NaCl}(\mathrm{P} 4)\end{array}$ & 5.35 & 4.05 \\
\hline
\end{tabular}


kang (BB) 10,7 $\pm 3,4$ g/ekor (betina) dan $8,1 \pm 2,3$ g/ekor (jantan) sesuai kriteria Muzahar et al. (2019). Induk siput sebelum perlakuan diaklimatisasi dalam air laut bersalinitas $30 \mathrm{ppt}$ dalam bak fiber berkapasitas 1ton selama 48 jam. Induk selama aklimatisasi diberi pakan berupa sedimen lumpur yang diambil dari habitat alaminya. Ovaprim ${ }^{\circledR}$ yang digunakan produksi Syndel-India, dan hCG merek Chorulon ${ }^{\mathrm{TM}}$ produksi MSD-Netherland.

Semua induk siput gonggong betina diberi suntikan larutan sesuai dosis seperti terlihat pada Table 1, sedangkan semua induk jantan diberi suntikan ovaprim ${ }^{\circledR}$ sebanyak 4,05 $\mu$ L/ekor. Jarum suntik berukuran $0,60 \times 32 \mathrm{~mm}\left(23 \mathrm{G} \times 1 \frac{1 / 4}{4}\right)$ digunakan untuk memasukkan larutan hormon pada bagian otot kaki siput (Muzahar et al., 2019). Induk pascasuntik dipelihara dalam akuarium dengan densitas 7 pasang/ akuarium selama 13 hari. Induk siput selama masa perlakuan pemijahan diberi pakan berupa sedimen lumpur. Penambahan air dalam akuarium hanya dilakukan untuk mengganti air yang menguap.

\subsection{Parameter Uji dan Analisis Data}

Parameter yang diamati terdiri atas (1) jumlah induk yang memijah, (2) jumlah telur dikeluarkan oleh masing-masing induk, (3) waktu latensi, dan (4) histologi gonad siput gonggong yang memijah dan tidak mijah. Telur yang dikeluarkan oleh induk diambil sejumlah tertentu secara acak kemudian ditimbang dan dihitung. Uji Kruskal Wallis digunakan untuk menganalisis jumlah induk yang memijah dan analysis of variance (ANOVA) untuk menganalisis data jumlah telur yang dikeluarkan oleh induk siput gonggong, dan bila terdapat perbedaan nyata dilanjutkan dengan uji Duncan. Data waktu latensi induk dan analisis histologi gonad induk siput gonggong perlakuan dianalisis dan disajikan secara deskriptif. Analisis data secara statistik dilakukan dengan bantuan software SPSS versi 16.

\section{HASIL DAN PEMBAHASAN}

\subsection{Hasil dan Pembahasan}

\subsubsection{Jumlah Induk Mijah, Jumlah Telur Dikeluarkan dan Waktu Latensi}

Persentase jumlah induk siput gonggong betina yang memijah dan waktu latensinya disajikan pada Figure 1, serta jumlah rata-rata telur yang dikeluarkan (fekunditas) ditampilkan pada Figure 2.

Induk siput gonggong betina ditemukan pertama kali memijah (latency time tercepat) pada hari ke-2 pengamatan yaitu pada perlakuan suntikan $0,5 \mu \mathrm{L} / \mathrm{g} \quad \mathrm{BB}$ ovaprim (P2) dan terakhir pada hari ke-13 pada perlakuan suntikan $0,5 \mu \mathrm{L} / \mathrm{g}$ BB hCG (P1). Waktu latensi pada semua induk perlakuan beragam, namun umumnya induk memijah pada hari ke-2 dan ke-3. Waktu latensi tercepat pada perlakuan pemberian suntikan $0,5 \mu \mathrm{L} / \mathrm{g}$ BB ovaprim (P2) yang diperoleh pada penelitian ini sama dengan hasil Muzahar et al. (2019) yang memberikan jenis, dosis hormon serta spesies hewan uji yang sama yaitu pada hari ke-2. Waktu latensi ini jauh lebih lambat dibandingkan dengan golongan ikan (finfish), seperti ikan gurami Ospronemous gouramy dan ikan tengadak $B$. schwanenfeldii yang diberi perlakuan dosis dan jenis hormon sama yaitu hanya 8-13 jam (Dewantoro et al., 2017). Jumlah induk yang memijah terbanyak adalah pada perlakuan suntikan $0,5 \mu \mathrm{L} / \mathrm{g}$ BB hCG (P1) yaitu 11 ekor $(52,38 \%)$, dan paling sedikit pada perlakuan suntikan $0,5 \mu \mathrm{L} / \mathrm{g}$ BB kombinasi hCG dan ovaprim (P3) yaitu 3 ekor (14,29\%). Pemakaian ovaprim dan hCG untuk menstimulasi pemijahan golongan gastropoda masih sangat sedikit dilakukan. Mekanisme kerja hormon hCG dan ovaprim yang diinjeksikan pada siput gonggong masih belum diketahui. Hal ini selaras dengan pendapat Appeldoorn (1995), bahwa hanya sedikit yang dipahami tentang kontrol hormonal dan sistem endokrin dalam reproduksi gastropoda. Pemberian ovaprim pada 
(a) $\quad P l=$ dosage $0.5 \mu \mathrm{L} / \mathrm{gBW}$ og $h C G$.

$P 2=$ dosage $0.5 \mu \mathrm{L} / \mathrm{g} B W$ of ovaprim.

$P 3=$ dosage $0.5 \mu \mathrm{L} / \mathrm{gBW}$ of $h \mathrm{CG}+$ ovaprim

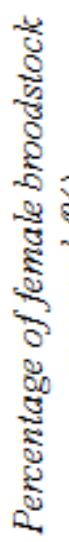

$\mathrm{P} 4=$ dosage $0.5 \mu \mathrm{L} / \mathrm{g} \mathrm{BW}$ of $\mathrm{NaCl}$

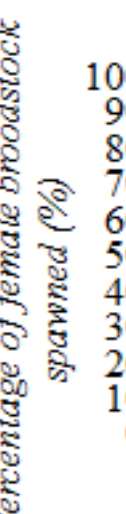

100
90
80
70
60
50
40
30
20
10
0
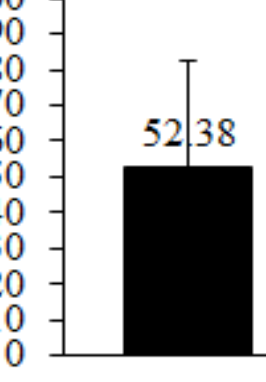

P1

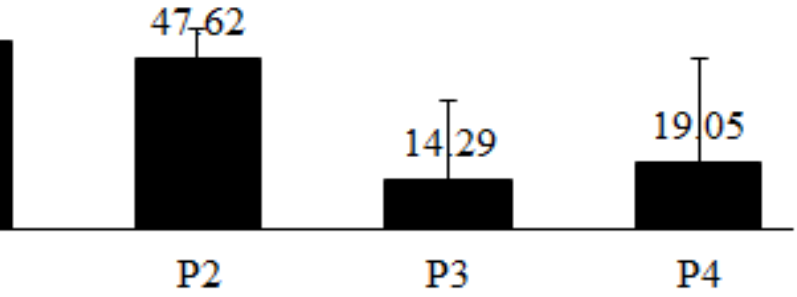

(b)

$\square \mathrm{P} 1 \backsim \mathrm{P} 2 \backsim \mathrm{P} 3 \backsim \mathrm{P} 4$

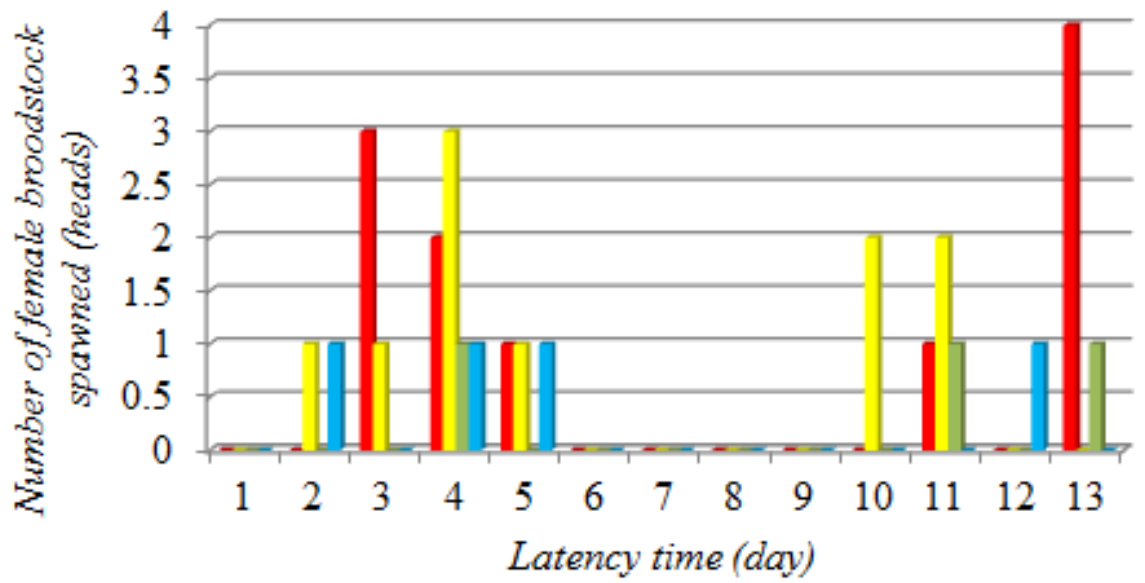

Figure 1. Percentage of female gonggong broodstock spawned (a) and its latency time (b).

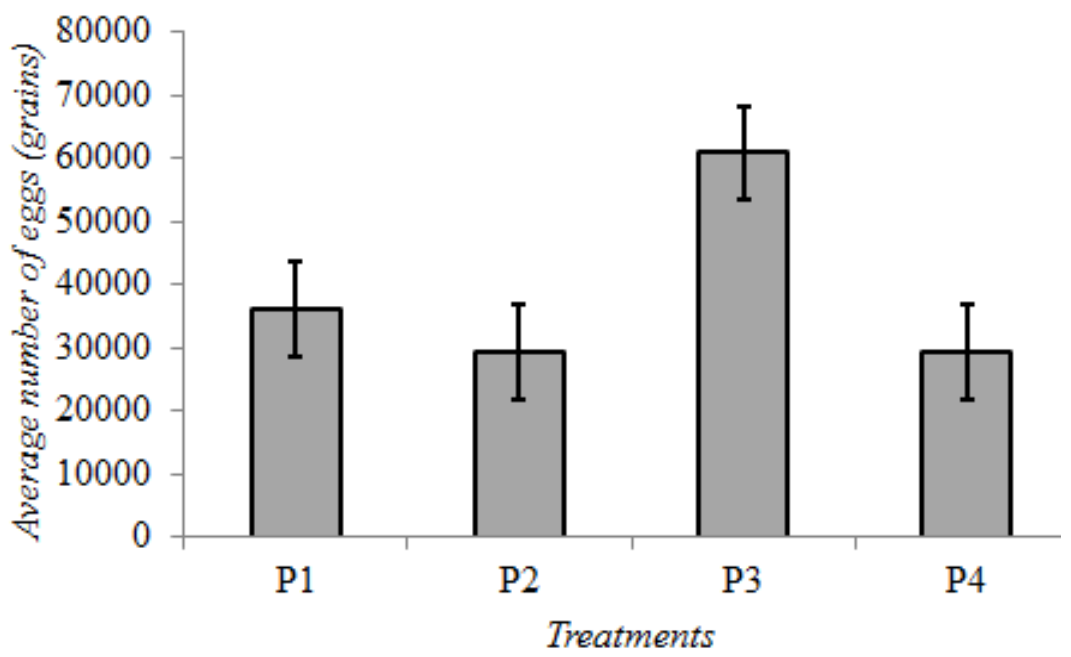

Figure 2. Average of eggs released (grain/head broodstock) on each treatments. 
ikan finfish berbeda pengaruhnya dengan golongan gastropoda. Ovaprim yang diberikan pada ikan meningkatkan efektifitas luteinizing hormone releasing hormone (LHRH) pada ikan karena sekresi hormon gonadotropin pada ikan berada di bawah kontrol ganda antara LHRH dan antidopamin (Zairin Jr., 2003) sehingga menstimulasi pemijahan ikan.

Jumlah rata-rata induk betina mijah secara keseluruhan adalah 33,33\%. Perbedaan persentase jumlah induk yang memijah berdasarkan uji Kruskal Wallis menunjukkan hasil tidak berbeda nyata di antara perlakuan $(\mathrm{P}>0,05)$, namun perlakuan suntikan $0,5 \mu \mathrm{L} / \mathrm{g}$ BB hormon hCG (P1) memiliki persentase induk betina mijah paling besar yaitu 52,38\%. Perbedaan persentase ini disebabkan oleh perbedaan tingkat kematangan gonad induk dan adanya beberapa induk yang tidak matang gonad sebagaimana hasil analisis histologi pada sampel gonad induk (Figure 3a). Adanya beberapa induk yang tidak matang gonad yang digunakan dalam penelitian ini disebabkan oleh sulitnya memastikan tingkat kematangan gonad. Kesulitan ini disebabkan posisi gonad gonggong berada di bagian dalam ujung cangkang mulai dari apeks sampai kira-kira sepertiga cangkang sehingga tidak dapat dilihat dari luar. Teknik penentuan induk matang gonad yang ada saat ini hanya berdasarkan panjang cangkang total. Oleh karena itu, penemuan teknik baru dalam menentukan kematangan gonad gonggong perlu dikembangkan. Persentase induk mijah tersebut $(0,5 \mu \mathrm{L} / \mathrm{g}$ BB hormon hCG, P1), dan perlakuan dosis $0,5 \mu \mathrm{L} / \mathrm{g} \mathrm{BB}$ ovaprim $(42,62 \%)$ pada penelitian ini memperlihatkan persentase hasil yang jauh lebih tinggi dibanding hasil Muzahar et al. (2019) yang hanya sebesar $34,48 \%$. Perlakuan pemberian suntikan $0,5 \mu \mathrm{L} / \mathrm{g}$ BB hormon hCG (P1) pada penelitian ini memberikan respons lebih baik untuk menstimulasi pemijahan induk siput gonggong betina berdasarkan persentase induk yang memijah $(52,38 \%)$. Hasil ini berbeda dengan kesimpulan dari
Nur et al. (2017) yang memberikan perlakuan jenis hormon yang sama pada finfish ikan agamysis (Agamyxis albomaculatus) yaitu bahwa penggunaan kombinasi hormon hCG dosis $500 \mathrm{IU} / \mathrm{kg}+$ ovaprim dosis 0,7 $\mathrm{mL} / \mathrm{kg}$ memberikan respons terbaik dibanding penggunaan hormon tunggal hCG atau ovaprim saja. Faktor yang ikut menentukan keberhasilan pemijahan gastropoda adalah musim. Produksi dan biomas siput Strombus canarium lebih tinggi pada musim hujan dibanding musim kemarau, dimulai bulan Nopember sampai bulan Maret (Cob, 2008), dan lama penyinaran (foto periodesitas) (Cala et al. 2012).

Jumlah telur yang dikeluarkan oleh masing-masing induk betina berbeda-beda pada semua perlakuan. Jumlah rata-rata tertinggi telur yang dikeluarkan oleh induk betina terdapat pada perlakuan suntikan 0,5 $\mu \mathrm{L} / \mathrm{g}$ BB kombinasi hormon hCG dan ovaprim (P3) yaitu $60.806 \pm 32.539$ butir/ ekor, dan terendah pada perlakuan suntikan $0,5 \mu \mathrm{L} / \mathrm{g} \mathrm{BB} \mathrm{NaCl}(\mathrm{P} 4)$ yaitu 29.179 \pm 25.160 butir/ekor. Jumlah rata-rata secara keseluruhan telur yang dikeluarkan sebesar 38.852 butir/ekor. Jumlah rata-rata telur yang dikeluarkan oleh induk betina siput gonggong berdasarkan analysis of variance (ANOVA) tidak berbeda nyata di antara perlakuan $(\mathrm{P}>0,05)$. Hasil ini disebabkan oleh jumlah telur yang dikeluarkan oleh masing-masing induk pada semua perlakuan sangat bervariasi dengan selisih yang besar antara jumlah terkecil dan terbesar. Faktor penyebab lainnya adalah perkembangan sel telur pada gonad betina pada ketiga perlakuan tidak seragam. Pemberian suntikan $0,5 \mu \mathrm{L} / \mathrm{g}$ BB kombinasi hormon hCG dan ovaprim (P3) yang memberikan hasil lebih baik dalam penelitian ini sejalan dengan hasil Nur et al. (2017) pada golongan ikan (finfish) yaitu secara umum perlakuan penggunaan kombinasi hCG 500 IU dengan ovaprim $0,7 \mathrm{~mL} / \mathrm{kg}$ bobot badan ikan agamysis menghasilkan telur yang lebih baik dibanding dengan perlakuan hormon tunggal. Fungsi pemberian hCG adalah me- 
nyeragamkan tingkat kematangan akhir telur dan menyiapkan telur yang matang untuk diovulasikan sehingga dapat menaikkan tingkat kepekaan oosit pada pada saat pemberian ovaprim (Cacot et al., 2002). Jumlah rata-rata telur yang dikeluarkan oleh induk betina baik pada setiap perlakuan maupun secara keseluruhan dalam penelitian ini lebih rendah daripada hasil Muzahar et al. (2019) yaitu 39.347 \pm 16.667 butir/ekor. Perbedaan jumlah telur yang dikeluarkan oleh masing-masing induk disebabkan perbedaan tingkat kematangan telur dalam masing-masing gonad induk betina (Figure 3). Telur-telur matang secara keseluruhan akan dikeluarkan oleh induk betina secara total dan jika belum matang maka terjadi pemijahan secara parsial. Jumlah telur yang dikeluarkan oleh beberapa golongan siput ketika memijah memang bervariasi, sebagai bukti pada keong dog conch (Strombus canarium) berkisar antara $48.745 \pm 877$ sampai 93.643 \pm 1.685 butir/ekor (Cob et al., 2009), keong gonggong (S. turturella) dari laut Bangka sebanyak 75.000-95.000 butir (Dody, 2012), keong queen conch ( $S$. gigas) sebesar 400.000 butir/ekor (Davis, 2005), dan pada siput lola (Trochus niloticus) antara $3 \times 10^{5}$ sampai dengan $1 \times 10^{6}$ butir/ekor (Pradina \& Dwiono, 1994). Faktor lingkungan hidup tempat individu ikan berada, kondisi fisiologis, umur, jenis ikan, kepadatan populasi, ukuran tubuh, makanan, dan sifat ikan merupakan penyebab adanya variasi jumlah telur yang dikeluarkan (fekunditas) ikan (Yildirim et al., 2006). Beberapa faktor penting di atas diduga juga berlaku pada siput gonggong.

\subsubsection{Profil Histologi Gonad Induk yang Mijah dan Tidak Mijah \\ Pofil mikroskopis histologis gonad} induk yang mijah dan tidak mijah ditampilkan pada Figure 3. Histologi gonad induk
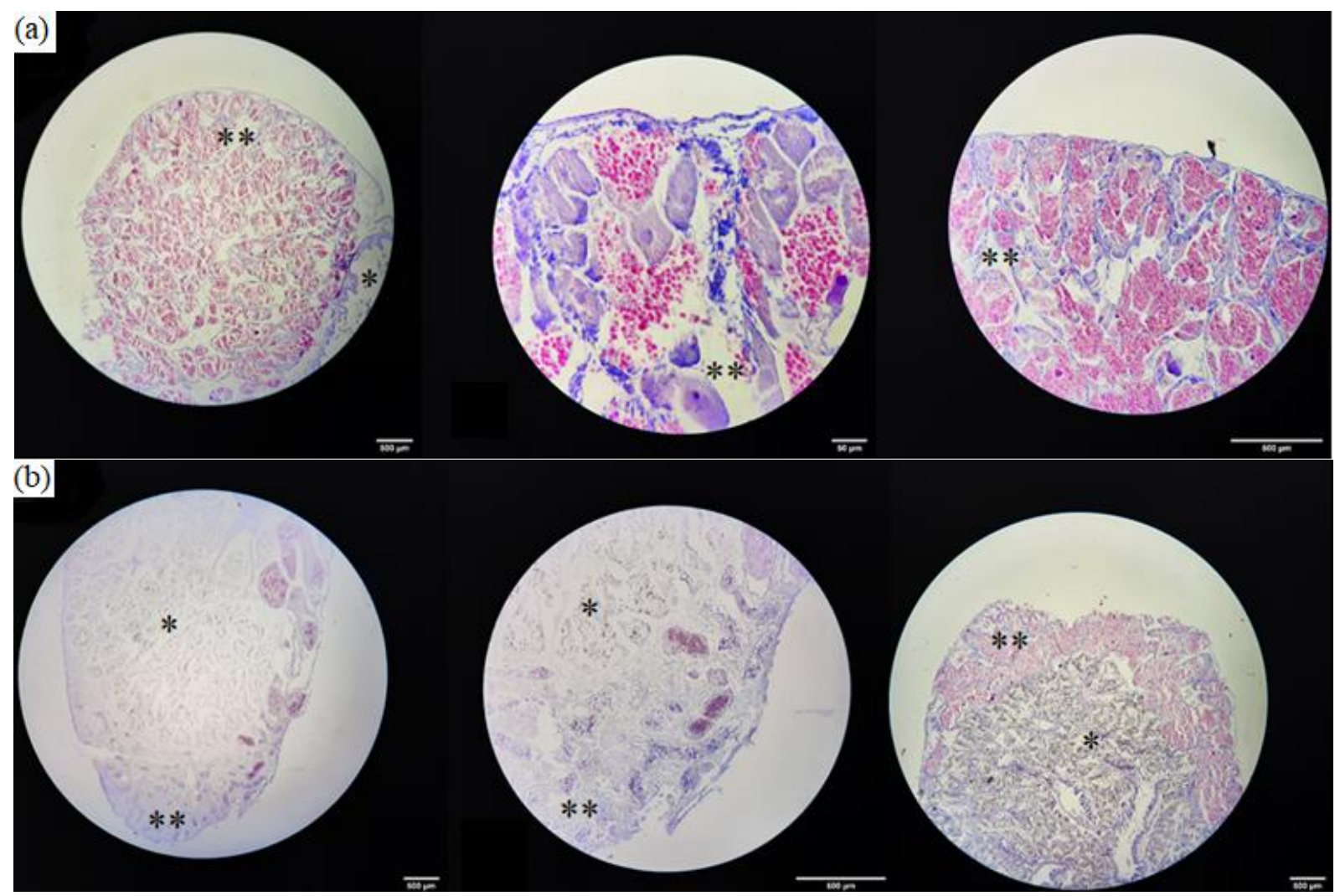

Figure 3. Gonadal histological profile of broodstock spawned (a), and gonadal histological profile of broodstock not spawned (b); *visceral, ** gonadal. 
siput gonggong perlakuan yang memijah menunjukkan perkembangan yang baik, namun sebagian kecil perkembangan telurnya tidak seragam terutama pada ujung luar jaringan gonad, sedangkan pada induk gonggong perlakuan yang tidak memijah tampilan gonadnya memiliki telur yang tidak/sedikit sekali yang berkembang.

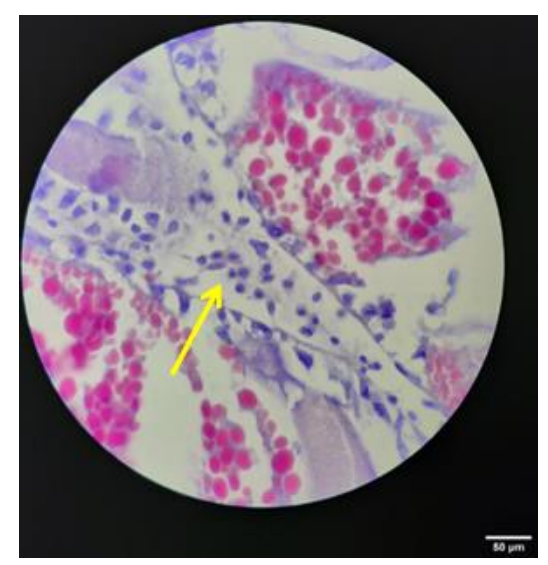

Figure 4. The collection of gonggong conch spermatozoa observed in famale gonad (yellow arrow).

Profil perkembangan gonad indukinduk gonggong perlakuan baik yang memijah dan tidak memijah yang beragam tersebut mirip dengan yang terjadi pada siput Lambis-lambis yang masih dalam satu famili Strombidae. Tingkat kematangan gonad siput Lambis diamati terdiri atas TKG I sampai TKG IV yang mengindikasikan proses pembentukan dan pematangan gonad serta pemijahan yang terjadi sepanjang tahun (Widyastuti \& Aji, 2016). Hasil ini juga selaras dengan temuan Leimena \& Subahar (2006) pada keong lola (Trochus niloticus) betina, yaitu bahwa dalam satu individu terdapat beberapa tahap perkembangan gonad, yaitu oosit muda, oosit yang sedang berkembang, dan oosit matang. Kondisi seperti ini mengindikasikan bahwa proses perkembangan gonad keong lola terjadi terus menerus sehingga pemijahannya berlangsung sepanjang tahun, dan keadaan ini diduga juga terjadi pada siput gonggong. Proses perkembangan gonad beberapa jenis siput laut secara umum berlangsung terus menerus sepanjang tahun seperti pada siput laut Turbo torquatus (Ward \& Davis, 2002).

Proses pembuahan sel telur oleh sel sperma terjadi di dalam tubuh individu betina yang dibuktikan dengan ditemukannya sperma dalam seluruh sampel gonad induk gonggong betina yang diamati. Sampel kumpulan sperma yang berhasil diamati dalam gonad induk gonggong betina ditampilkan pada Figure 4.

\section{KESIMPULAN}

Pemberian hCG dosis $0,5 \mu \mathrm{L} / \mathrm{g}$ BB (P1) memiliki persentase pemijahan tertinggi dibanding perlakuan lain, yaitu 52,38\%. Jumlah telur yang dikeluarkan oleh induk dengan perlakuan pemberian kombinasi hormon hCG dan ovaprim (P3) dosis 0,5 $\mu \mathrm{L} / \mathrm{g}$ BB memiliki jumlah telur terbanyak, yaitu $60.806 \pm 32.539$ butir/ekor. Waktu latensi pada semua perlakuan umumnya dimulai pada hari ke-2 dan ke-3. Histologi gonad induk gonggong betina menunjukkan perkembangan telur yang tidak seragam. Berdasarkan persentase induk yang memijah dan keseluruhan para-meter yang diamati dapat disimpulkan bahwa pemberian suntikan hCG dosis $0,5 \mu \mathrm{L} / \mathrm{g}$ BB (P1) memberikan respons lebih baik dibanding dua perlakuan lain.

\section{UCAPAN TERIMA KASIH}

Penelitian ini didanai oleh Research Grant Fakultas Ilmu Kelautan dan Perikanan-Universitas Maritim Raja Ali Haji Tahun 2020. Terima kasih disampaikan kepada Dekan dan WD II FIKP UMRAH, Kepala Marine Aquaculture LaboratoryBDP, Kepala Marine Biology Laboratory FIKP-UMRAH atas bantuan fasilitas dan dukungannya dalam penelitian ini, sahabatku Zulpikar, S.Pi., Hamzah, Budi Primulia, M.AP., Hary Wibowo, M.Ak., Agus Muslim, M.Si., Dian Novitasari, M.Si., Firdaus, S.Pi., para mahasiswa Rian 
Sukamto dan Ad durunnafis serta semua pihak yang telah membantu Penulis dalam menyelesaikan penelitian dan tulisan ini.

\section{DAFTAR PUSTAKA}

Afriani, D.T. 2016. Peranan pembenihan ikan dalam usaha budidaya ikan. $J$. Warta, 49: 1-9. https://doi.org/10.46576/wdw.v0i49. 158

Appeldoorn, R.S. 1995. Potential depensatory mechanisms operating on reproductive output in gonochoristic molluscs, with particular reference to strombid gastropods. ICES mar. Sei. Symp, 199: 13-18 pp.

Cacot, P., M. Legendre, T.Q. Dan, L.T. Hung, P.T. Liem, C. Mariojouls, \& J. Lazard. 2002. Induced ovulation of Pangasius bocourti (Sauvage, 1880) with a progressive hCG treatment. Aquaculture, 213: 199-206.

Cala, Y.R., A. de Jesús-Navarrete, F.A. Ocana, \& J. Oliva-Rivera. 2013. Density and reproduction of the queen conch Strombus gigas at Cabo Cruz, Desembarco del Granma National Park, Cuba. J. Tropical. Biology, 61(2): 645-655.

https://www.redalyc.org/pdf/449/449 27436014.pdf

Cob, Z.C., A. Arshad, M.A. Ghaffar, J.S. Bujang, \& W.L.W. Muda. 2009. Development and growth of larvae of the dog conch, Strombus canarium (Mollusca: Gastropoda), in the laboratory. J. of Zoology Study, 48(1): 1-11.

https://citeseerx.ist.psu.edu/viewdoc/ download?doi=10.1.1.598.5147\&rep $=$ rep $1 \&$ type $=$ pdf

Cob, Z.C., A. Arshad, M.A. Ghaffar, \& J.S. Bujang. 2008. Sexual maturity and sex determination in Strombus canarium. J. Biological Science, 8(3): 616-621. https://doi.org/10.3923/jbs.2008.616. 621

Dewantoro, E., N.R. Yudhaswara, \& Farida. 2017. Pengaruh penyuntikan hormon ovaprim terhadap kinerja pemijahan ikan tengadak. J. Ruaya, 5(2): 1-9. http://doi.org/10.29406/rya.v5i2.715

Dody, S. 2012. Pemijahan dan perkembangan larva siput gonggong (Strombus turturella). J. Ilmu dan Teknologi Kelautan Tropis, 1(4): 107-113. https://doi.org/10.29244/jitkt.v4i1.78 11

Effendie, M.I. 2002. Biologi Perikanan. Yayasan Pustaka Nusatama. Yogyakarta. 163 p.

Leimena, H.E.P. \& S.S.T Subahar. 2006. Potensi reproduksi keong lola (Trochus niloticus) di Pulau Saparua, Maluku Tengah. Hayati, 13(2):4952. https://doi.org/10.4308/hjb.13.2.49

Lu, M., T. Horiguchi, H. Shiraishi, Y. Shibata, M. Abo, A. Okubo, \& S. Yamazaki. 2001. Discrepancy of analytical values of steroid hormones in marine gastropods between GC/MS and ELISA. J. Analytical Sciences, 17:1619-1622. https://doi.org/10.14891/analscisp.17 icas.0.11619.0

Mulah, A., T.S. Raza'I, \& W.K.A. Putra. 2017. Efektivitas penggunaan hormon human chorionic gonadotropin (hCG) dan ovaprim terhadap waktu latensi dan fekunditas dalam pemijahan ikan bawal bintang (Trachinotus blochii). J. Intek Akuakultur, 1(2): 1-6. https://doi.org/10.31629/intek.v1i2.2 60

Muzahar, M. Zairin Jr., F. Yulianda, M.A. Suprayudi, Alimuddin, \& I. Effendi. 2019. Pemijahan semi-buatan siput gonggong Laevistrombus turturella dengan induksi kombinasi hormon LHRH-a dan antidopamin. J. Riset Akuakultur, 14(4): 1-6. 
http://doi.org/10.15578/jra.14.4.2019 $.225-232$

Muzahar, M. Zairin Jr., F. Yulianda, M.A. Suprayudi, Alimuddin, \& I. Effendi. 2018 The phenotype comparison and genotype analysis of five Indonesian Laevistrombus sp. variants as a basis of species selection for aquaculture. AACL Bioflux, 11(4): 1164-1172. http://www.bioflux.com.ro/docs/201 8.1164-1172.pdf

Muzahar \& A.A. Hakim. 2018. Spawning and development of $\mathrm{dog}$ conch Strombus sp. larvae in the laboratory. J. Ilmu dan Teknologi Kelautan Tropis, 10(1): 209-216. http://doi.org/10.29244/jitkt.v10i1.18 607

Muzahar \& L. Viruly. 2013. Karakterisasi kimia, sensori dan laju pemijahan gonggong (Strombus sp.) sebagai ikon Kepulauan Riau. J. Dinamika Maritim, 3(2): 20-29.

Nur, B., A. Permana, A. Priyadi, S.Z. Mustofa \& S. Murniasih. 2017. Induksi ovulasi dan pemijahan ikan agamysis Agamyxis albomaculatus menggunakan hormon yang berbeda. J. Riset Akuakultur, 12(2): 169-177. http://doi.org/10.15578/jra.12.2.2017 .169-177.

Pradina \& S.A.P Dwiono. 1994. Karakteristik fase-fase perkembangan ovaria lola, Trochus niloticus (Moluska, Gastropoda). PRM LIPI, 8: 15-21.

http://doi.org/10.1016/S19783019(16)30380-1

Putra, W.K.A., T.S. Raza'i, R.T. Zulfikar, R. Handrianto, Zulpikar, \& Fauzanadi. 2018. Kajian pemijahan ikan bawal bintang (Trachinotus blochii) secara induksi hormonal. Intek Akuakultur, 2(1): 54-62.

https://ojs.umrah.ac.id/index.php/inte k/article/download/540/388/

Sinjal, H. 2014. Efektifitas ovaprim terhadap lama waktu pemijahan, daya tetas telur dan sintasan larva ikan lele dumbo Clarias gariepinus. J. Budidaya Perairan, 2(1): 14-21.

https://doi.org/10.35800/bdp.2.1.201 4.3788

Wang, C. \& R.P. Croll. 2006. Effects of sex steroids on spawning in the sea scallop, Placopecten magellanicus. Aquaculture, 256: 423-432. https://doi.org/10.1016/j.aquaculture. 2006.01.017

Ward, D.W. \& A.R. Davis. 2002. Reproduction of the turban shell Turbo torquatus Gmelin 1791 (Mollusca: Gastropoda) in New South Wales, Australia. Mar. Freshwater Res., 53: 85-91. https://doi.org/10.1071/MF00066

Widyastuti, A. \& L.P. Aji. 2016. Beberapa Aspek Reproduksi Siput Lambis lambis di Pesisir Perairan Yenusi, Biak. J. Oseanologi dan Limnologi di Indonesia, 1(3): 1-9. http://doi.org/10.14203/oldi.2016.v1i 3.74

Yildirim, A.H.I., Haliloglu, O. Erdogan, \& M. Turkmen. 2006. Some reproduction characteristics of Chalcalburnus mossulini (Heckel, 1843) Inhabiting the Karasau River (Erzurum, Turkey). Tubitak. Turk $J$. Zool., 31(27): 193-200.

https://journals.tubitak.gov.tr/zoolog y/issues/zoo-07-31-2/zoo-31-2-150603-2.pdf

Yudha, H.T., A.O. Sudrajat, \& Haryanti. 2017. Pengaruh rangsangan hormon aromatase inhibitor dan oodev terhadap perubahan kelamin dan perkembangan gonad ikan kerapu sunu (Plectropomus leopardus). JRA, 12(4): 325-333. http://doi.org/10.15578/jra.12.4.2017 .325-333

Yan, H., Q. Li, W. Liu, Q. Ke, R. Yu, \& L. Kong. 2011. Seasonal changes of oestradiol-17 $\beta$ and testosterone concentrations in the gonad of the 
razor clam (Sinonovacula constricta, Lamarck, 1818). J. of Molluscan Studies Advance, 0: 1-7. https://doi.org/10.1093/mollus/eyq04 5.

Zairin Jr., M. 2003. Endokrinologi dan perannya bagi masa depan perikanan
Indonesia. Orasi ilmiah guru besar Institut Pertanian Bogor. Bogor. 70 p.

Received : 1 August 2020

Reviewed : 10 October 2020

Accepted : 10 December 2020 
